\title{
Trends in the incidence and mortality of kidney cancer in Lithuania from 1993 to 2012
}

Aušvydas Patašius ${ }^{1}$,

Agnè Ulyte் ${ }^{2}$,

Albertas Ulys ${ }^{1}$,

Giedrè Smailyt $\dot{e}^{1}$

${ }^{1}$ National Cancer Institute,

Vilnius, Lithuania

${ }^{2}$ Faculty of Medicine,

Vilnius University,

Vilnius, Lithuania
Background. The aim of this paper is to analyse trends of kidney cancer incidence and mortality in Lithuania during the period of 1993 to 2012 using joinpoint regression models with special attention to changes in the distribution of stages.

Materials and methods. The study was based on all cases of kidney cancer reported to the Lithuanian Cancer Registry between 1993 and 2012. Age group-specific rates and standardized rates were calculated for each sex, using the direct method (world standard population). The joinpoint regression model was used to provide the estimated annual percentage change and to detect points in time where significant changes in the trends occur.

Results. During the study period the age-standardized incidence rates increased from $16.89 / 100,000$ in 1993 to $27.77 / 100,000$ in 2012 in males, and from 7.95/100,000 to $13.44 / 100,000$ in females. During this period, annual percentage changes in the age-standardized rates were $2.33 \%$ and $1.81 \%$ for males and females, respectively. The joinpoint analysis by stage of disease showed the highest increase in stage I kidney cancer, with statistically significant trend change in 2002 for males and in 2001 for females. During the study period, age-standardized mortality rates decreased from $10.42 / 100,000$ in 1993 to $8.96 / 100,000$ in 2012 in males, and from 4.54/100,000 to 3.9/100,000 in females.

Conclusions. The kidney cancer incidence rate in Lithuania rose during the period of 1993 to 2012. The detailed analysis by stage showed the most significant increase in organ-confined incidence of kidney cancer. A stable mortality trend for males and a decreasing mortality trend for females along with increased incidence of early stage kidney cancer indicate that both earlier detection and modern treatment modalities may contribute to the reduction of mortality.

Keywords: kidney cancer, incidence, mortality

Correspondence to: Aušvydas Patašius, National Cancer Institute, 1 Santariškių St., Vilnius 08406, Lithuania. Email: ausvydas.patasius@gmail.com 


\section{INTRODUCTION}

Kidney, renal pelvis, and ureteral cancer amounts to the seventh most common cancer and accounted for $3.3 \%$ of all new cancer cases diagnosed in Europe in 2012 (1). Compared with other cancers, kidney cancer is relatively rare, but worldwide incidence rates are steadily rising while mortality trends have stabilized in many highly developed countries (2).

The aetiology of kidney cancer is still largely unknown. In addition to obesity and hypertension, known risk factors for kidney cancer include cigarette smoking, diet, and diabetes. Occupational exposure and other environmental, genetic, and hormonal factors have been studied but without definitive conclusion $(3,4)$.

In the European countries, World population age-standardised incidence rates of kidney cancer vary considerably. The highest incidence rates in men and women are reported in the Czech Republic $(16.7 / 100,000)$, Lithuania $(13.2 / 100,000)$, and Slovakia $(12.5 / 100,000)$, contrasting to the surrounding regions. The renal cell carcinoma (RCC) mortality rate in Lithuania is 4.9 cases per 100,000 people, the highest mortality rate in the world. Currently there is no information on any genetic, lifestyle, or environmental factors that could explain such notable regional differences of incidence (5).

Kidney cancer incidence is rising in Lithuania, possibly due to diagnostic improvements (6). In this paper, we present an analysis of kidney cancer incidence and mortality trends in Lithuania during the period of 1993-2012 using joinpoint regression models with special attention to changes in the distribution of stages.

\section{MATERIALS AND METHODS}

The study was based on all cases of kidney cancer reported to the Lithuanian Cancer Registry during 1993-2012 (International Classification of Disease - Oncology, 1st edition, site codes 1890 for the period 1993-1997, 2nd and 3th edition, site codes C649 for the period 1998-2012, behaviour code 3). The Lithuanian Cancer Registry is a population-based registry which contains personal and demographic information (place of residence, sex, date of birth, vital status), as well as information on the diagnosis (cancer site, date of diagnosis, method of cancer verification) and death (date of death, cause of death) of all cancer patients in Lithuania. The population of Lithuania is around three million residents according to the 2011 census.

Only patients older than 15 years of age were analysed. Age-standardized incidence and mortality as well as group-specific incidence rates were calculated for each sex, using the direct method (world standard population). Corresponding population data by age, sex, and year were available from Statistics Lithuania. A detailed analysis by age and stage of disease was performed. During the study period, the TNM system was used for coding the stage of disease (4th, 5th, 6th, and 7th edition for periods 1993-2000, 2001-2007, 2008-2010 and 2011-2012, respectively). Renal cell carcinoma of kidney in 2012 amounted to $74.1 \%$ of all new cases, however, the large proportion of unspecified kidney cancer, especially in earlier periods, did not allow analysis of incidence trends by tumour morphology.

The joinpoint regression model was used to provide estimated annual percentage change (APC) and to detect points in time where significant changes in the trends occurred. For each of the identified trends, we also fitted a regression line to the natural logarithm of the rates using calendar year as a regression variable. Ninety-five per cent confidence intervals for APC were calculated. Changes were considered statistically significant if $p<0.05$. The joinpoint analysis was performed for all ages combined and age-specific rates for the age groups 15-44, 45-59, 60-74, and 75 and more, and for each stage of kidney cancer. Joinpoint software version 4.3.1.0 was used.

\section{RESULTS}

During the analyzed 20-year period, 12,015 kidney cancer cases were diagnosed in Lithuania. Detailed characteristics of the study group are shown in Table 1 . The total number of kidney cancer cases increased from 2370 in 1993-1997 to 3548 in 20082012. The number of stage I cancer cases increased by $3440 \%$.

Incidence. During the period of 1993 to 2012, kidney cancer incidence rates were considerably lower for females than for males, with female: male ratio 1:2. Kidney cancer incidence rates changed during the study period from $16.89 / 100,000$ in 1993 to $27.77 / 100,000$ in 2012 in males, and from $7.95 / 100,000$ to $13.44 / 100,000$ in females (Fig. 1). 
Table 1. Characteristics of the study group

\begin{tabular}{cccc|c|c|c|c|c}
\hline Number of cases & Males & Females & 1993-1997 & 1998-2002 & 2003-2007 & 2008-2012 & Change, \%* \\
\hline Total & 6940 & 5075 & 2370 & 2808 & 3289 & 3548 & 49.7 \\
\hline Stage I & 1803 & 1625 & 47 & 525 & 1230 & 1617 & 3440 \\
\hline Stage II & 1201 & 956 & 752 & 647 & 462 & 321 & -134 \\
\hline Stage III & 1425 & 1051 & 713 & 691 & 563 & 509 & -40 \\
\hline Stage IV & 1759 & 910 & 613 & 727 & 694 & 635 & 3.6 \\
\hline Unspecified & 752 & 533 & 235 & 219 & 340 & 490 & 108 \\
\hline $15-44$ & 445 & 241 & 166 & 175 & 194 & 190 & 14.45 \\
\hline $45-59$ & 2158 & 1218 & 703 & 745 & 793 & 1016 & 44.5 \\
\hline $60-74$ & 3205 & 2459 & 1197 & 1446 & 1533 & 1488 & 24.3 \\
\hline$>75$ & 1132 & 1157 & 304 & 442 & 689 & 854 & 180 \\
\hline
\end{tabular}

* 1993-1997 period vs. 2008-2012 period

Age-specific kidney cancer incidence rates are shown in Fig. 2. In both sexes kidney cancer incidence increased from the age 35-39 steadily up to 69 years, and decreased thereafter.

Results of the joinpoint analysis of incidence time trends are shown in Table 2. Annual percentage changes in the age-standardized rates over this period were $2.33 \%$ and $1.81 \%$ for males and females, respectively, without significant points of change. Age group analysis revealed that for the entire study period the rates increased significantly in all age groups for both sexes. The most rapid increase was found in the age group 75 years and above (APC 4.33 and 3.78 in males and females, respectively).

Results of the joinpoint analysis of trends by stage of disease for both sexes separately are shown in Table 3. The number of stage I kidney cancer increased from eight cases in 1993 to 377 cases in 2012. The joinpoint analysis by stage of disease showed the highest increase in stage I kidney cancer (with APC $12 \%$ per year for both sexes), with statistically significant change in trend in 2002 for males and in

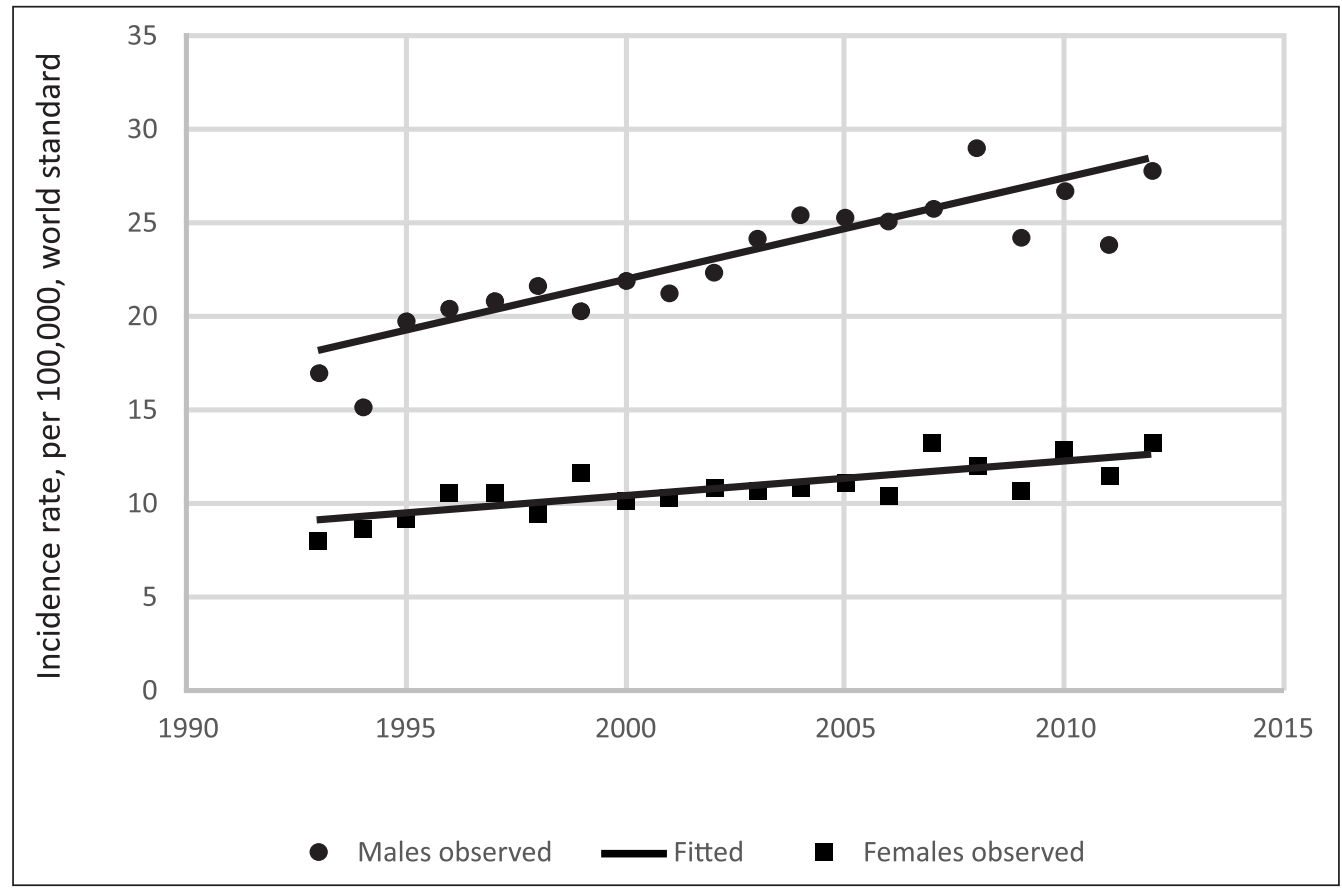

Fig. 1. Age-standardized incidence rates of kidney cancer by sex in Lithuania in 1993-2012 


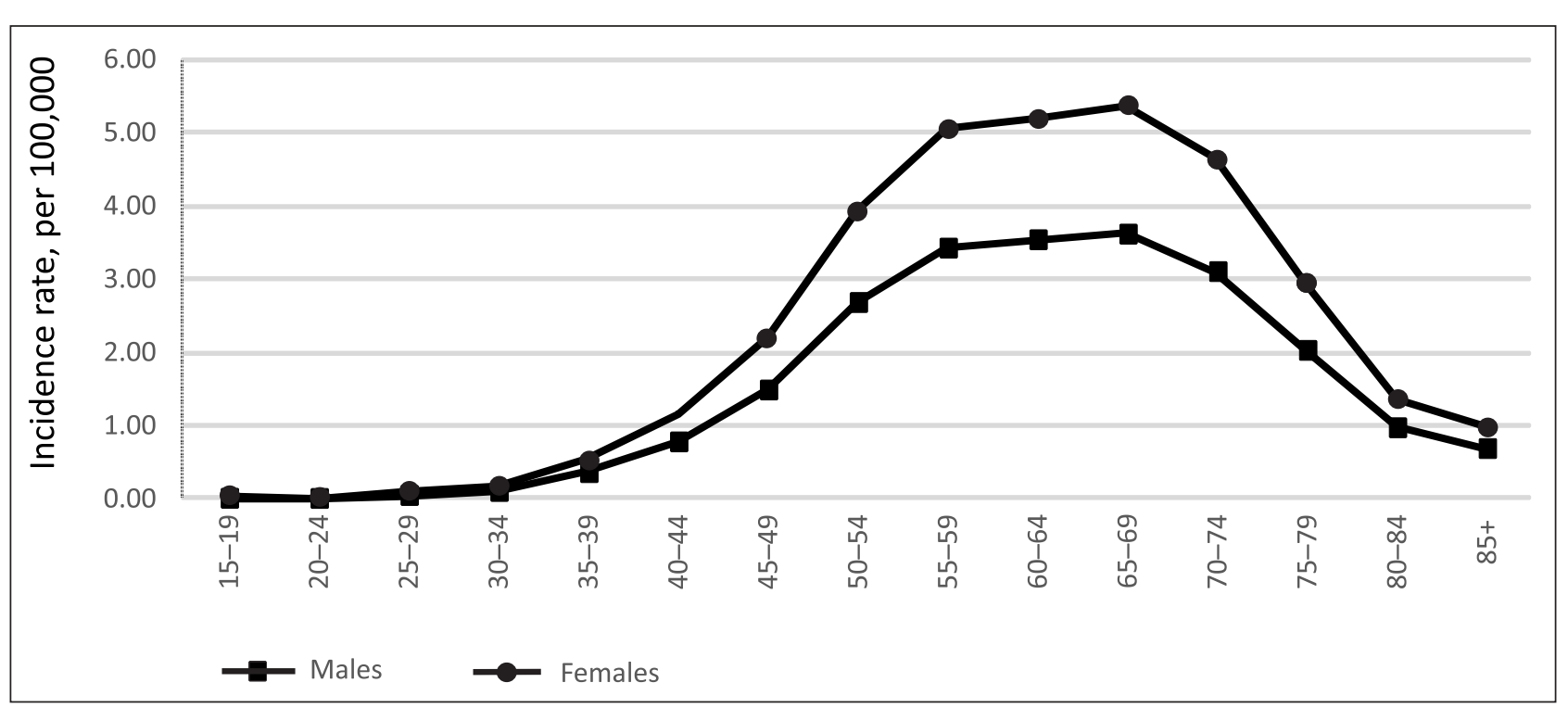

Fig. 2. Age-specific incidence rates of kidney cancer by sex in Lithuania 1993-2012

Table 2. Kidney cancer incidence rates and the joinpoint analysis, 1993-2012

\begin{tabular}{|c|c|c|c|c|c|}
\hline & \multicolumn{2}{|c|}{1993} & \multicolumn{2}{|c|}{2012} & \multirow{2}{*}{$\frac{1993-2012}{\text { APC }}$} \\
\hline & $\mathbf{N}$ & Rate & $\mathrm{N}$ & Rate & \\
\hline \multicolumn{6}{|l|}{ Males } \\
\hline \multicolumn{6}{|l|}{ Age (years) } \\
\hline $15-44$ & 20 & 2,46 & 23 & 3,87 & $2.28^{\star}$ \\
\hline $45-59$ & 85 & 29.76 & 120 & 39.87 & $2.22^{\star}$ \\
\hline $60-74$ & 113 & 64.05 & 198 & 110.99 & $1.87^{\star}$ \\
\hline$\geq 75$ & 24 & 46.55 & 97 & 127.50 & $4.33^{*}$ \\
\hline Standardized & 242 & 16.89 & 438 & 27.77 & $2.33^{\star}$ \\
\hline \multicolumn{6}{|l|}{ Females } \\
\hline \multicolumn{6}{|l|}{ Age (years) } \\
\hline $15-44$ & 6 & 0.74 & 15 & 2.53 & 1.16 \\
\hline $45-59$ & 52 & 15.31 & 71 & 20.52 & $1.51^{\star}$ \\
\hline $60-74$ & 95 & 33.69 & 143 & 52.10 & $1.63^{\star}$ \\
\hline$\geq 75$ & 21 & 18.41 & 109 & 59.40 & $3.78^{\star}$ \\
\hline Standardized & 174 & 7.95 & 338 & 13.44 & $1.81^{\star}$ \\
\hline
\end{tabular}

* statistically significant

Table 3. Kidney cancer incidence joinpoint analysis by stage in Lithuania, 1993-2012

\begin{tabular}{|c|c|c|c|c|c|c|c|c|c|}
\hline & \multicolumn{2}{|c|}{1993} & \multicolumn{2}{|c|}{2012} & \multirow{2}{*}{$\frac{\text { APC }}{1993-2012}$} & \multirow{2}{*}{ Trend 1} & \multirow{2}{*}{ APC } & \multirow{2}{*}{ Trend 2} & \multirow{2}{*}{ APC } \\
\hline & $\mathbf{N}$ & Rate & $\mathbf{N}$ & Rate & & & & & \\
\hline \multicolumn{10}{|l|}{ Males } \\
\hline Stage I & 5 & 0.36 & 208 & 13.53 & $11.87^{\star}$ & 1993-2002 & $50.89^{*}$ & 2002-2012 & $5.43^{\star}$ \\
\hline Stage II & 68 & 4.79 & 29 & 1.81 & $-5.56^{*}$ & 1993-1996 & 12.11 & 1996-2012 & $-7.22^{\star}$ \\
\hline Stage III & 71 & 4.98 & 62 & 4.03 & $-2.03^{\star}$ & 1993-1997 & 9.28 & 1997-2012 & $-3.49^{\star}$ \\
\hline Stage IV & 64 & 4.49 & 79 & 4.94 & -0.06 & 1993-2012 & -0.06 & & \\
\hline Unspecified & 34 & 0.69 & 60 & 1.85 & $3.49^{\star}$ & $1993-2012$ & $3.49^{*}$ & & \\
\hline
\end{tabular}


Table 3. (continued)

\begin{tabular}{|c|c|c|c|c|c|c|c|c|c|}
\hline & \multicolumn{2}{|c|}{1993} & \multicolumn{2}{|c|}{2012} & \multirow{2}{*}{$\begin{array}{c}\text { APC } \\
1993-2012\end{array}$} & \multirow{2}{*}{ Trend 1} & \multirow{2}{*}{ APC } & \multirow{2}{*}{ Trend 2} & \multirow{2}{*}{ APC } \\
\hline & $\mathrm{N}$ & Rate & $\mathrm{N}$ & Rate & & & & & \\
\hline \multicolumn{10}{|l|}{ Females } \\
\hline Stage I & 3 & 0.13 & 169 & 7.37 & 11.97 & 1993-2001 & 61.04 & $2001-2012$ & 6.68 \\
\hline Stage II & 52 & 2.42 & 21 & 0.96 & $-7.28^{\star}$ & 1993-1996 & 18.28 & 1996-2012 & $-9.47^{\star}$ \\
\hline Stage III & 55 & 2.6 & 59 & 2.17 & $-4.05^{\star}$ & 1993-1997 & 3.69 & 1997-2012 & $-5.23^{\star}$ \\
\hline Stage IV & 49 & 2.11 & 33 & 1.09 & -1.67 & 1993-2012 & -1.67 & & \\
\hline Unspecified & 15 & 2.27 & 56 & 3.46 & $4.86^{\star}$ & $1993-2012$ & $4.86^{*}$ & & \\
\hline
\end{tabular}

2001 for females. Incidence rates of stage II and stage III incidence rose until 1996 and 1997, respectively, for both sexes, and decreased thereafter. The rates of stage IV kidney cancer did not change significantly, but the incidence of unspecified stage kidney cancer increased. Incidence changes during the whole study period by stage for males and females are shown in Figs. 3 and 4.
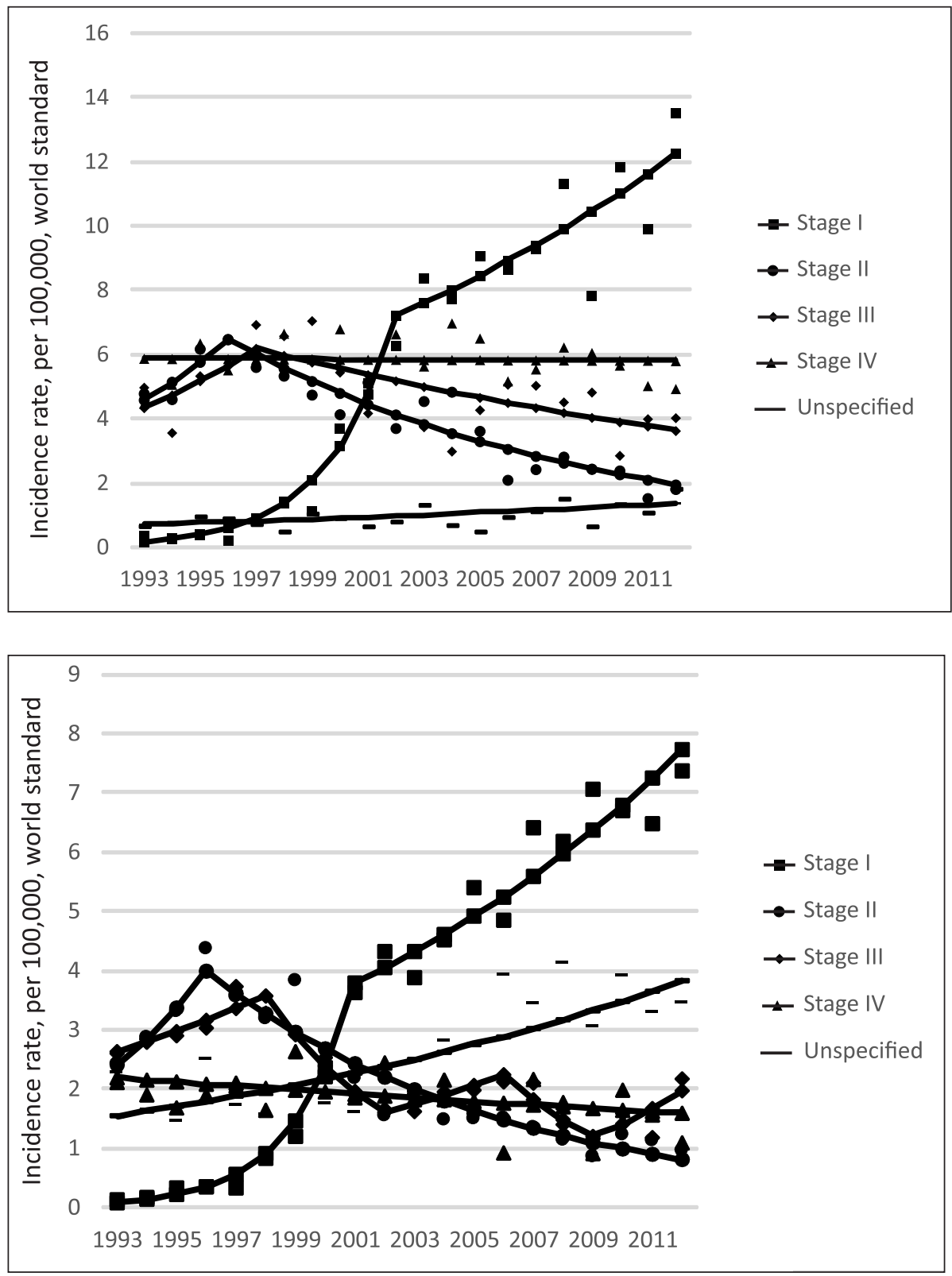

Fig. 3. Changes in male incidence rates of kidney cancer by stage in Lithuania, 19932012

Fig. 4. Changes in female incidence rates of kidney cancer by stage in Lithuania, 1993-2012 


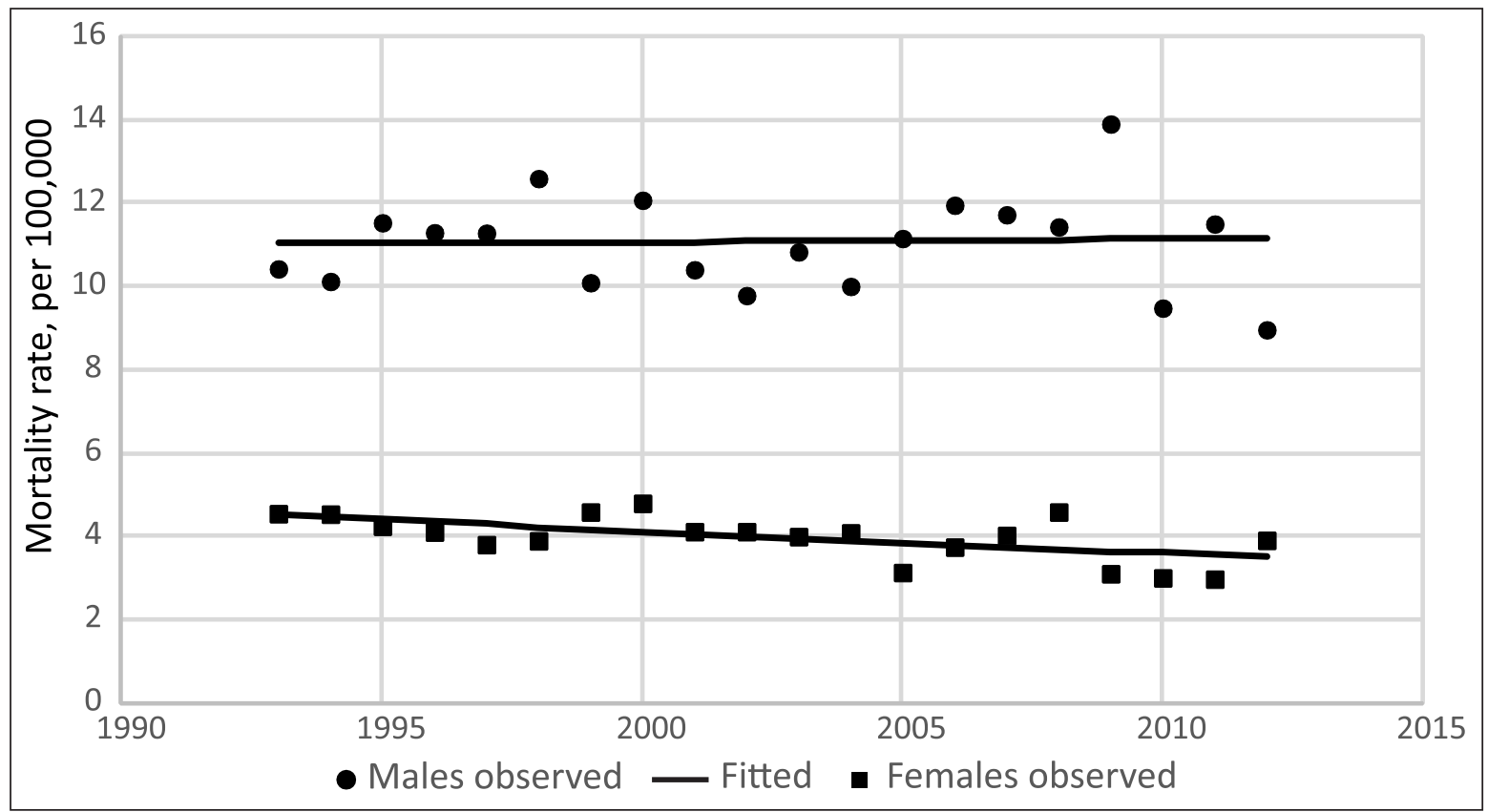

Fig. 5. Age-standardized kidney cancer mortality rates by sex in Lithuania, 1993-2012

Mortality. Mortality changes are shown in Fig. 5. During the study period, kidney cancer mortality rates changed from $10.42 / 100,000$ in 1993 to 8.96/100,000 in 2012 in males and from $4.54 / 100,000$ to $3.9 / 100,000$ in females. The joinpoint analysis showed a non-significant estimated annual percentage change of $0.08 \%$ in males and a significant change by $-1.35 \%$ in females.

\section{DISCUSSION}

In Lithuania, kidney cancer incidence rates were on the rise during the 1993-2012 period in both sexes. The greatest increase was observed in males and in females aged 75 years and above, and for stage I tumours. The rising incidence of kidney cancer in our study is consistent with the rapidly increasing incidence reported worldwide $(2,3$, $6-10,12)$. In the most recent analysis of the global burden of urologic cancers, the trend has been attributed to the population growth (35.0\%), changes in age structure $(34.7 \%)$, and increasing incidence rates (37.1\%) (7).

The recent increase in kidney cancer incidence may be partly attributed to the advances in diagnostic/imaging techniques and their wider application. The increasing use of imaging technologies (e.g., ultrasonography, computed tomography, magnetic resonance imaging) has likely resulted in greater detection of kidney cancer, especially of smaller tumours (8-12). Frequent use of ultrasonography and cross-sectional imaging is associated with incidental detection of many asymptomatic kidney tumours. Currently, 50\% of kidney cancer cases in Western countries are found incidentally on cross-sectional imaging (9).

During the studied period, we identified the highest increase in stage I kidney cancer with an APC of $12 \%$ per year for both sexes. Incidence of stage I tumours was increasing by $50-60 \%$ per year until 2001-2002, and for the later period by $5-7 \%$. A slower increase of stage I kidney tumours after 2001 could be attributed to the change of the TNM edition used in the country. The first TNM classification for malignant tumours was issued in 1943 (10). After a decade the first kidney cancer staging was established by Flocks and Kadesky based on anatomical characteristics and dissemination (11). The first classification of stages based on the TNM system was issued by the Union for International Cancer Control (UICC). Since 1987, there were several modifications of this classification system $(12,13)$. Most important was the fifth edition issued in 1997, where the cutoff point for T1 tumours was $2.5 \mathrm{~cm}$, and for T2 tumours $7 \mathrm{~cm}$. However, in the previous $1993 \mathrm{stag}-$ ing system supplement, T2 tumours were defined by a larger size and finally in revised edition of 1997 changed with the recommendation of $7 \mathrm{~cm}$ as the cut-off point for T1-T2. Due to the clinical 
demand and increasing application of nephron sparing surgery, the 2002 revision sub-staged T1 primary tumour into Tla (tumour $\leq 4 \mathrm{~cm}$ ) and T1b (tumour of 4-7 cm) (14). In our study, 4th and 5th editions of the TNM staging system were used for periods 1993-2000 and 2001-2007, respectively, and major changes in organ-confined disease staging could reflect trends of kidney cancer incidence in Lithuania.

In this study, the incidence of stage II and III kidney cancer was on the rise until 1996-1997 and decreased thereafter due to the appearance of computed tomography in the national guidelines of kidney cancer diagnostics and treatment.

Abdominal ultrasound is widely used to investigate a possible renal aetiology of hypertension and end organ damage (15), leading to a greater detection of asymptomatic renal masses (16). Combined with wide use of computed tomography and magnetic resonance imaging in kidney cancer diagnostics, this has lead to the migration of the pathologic stage from locally advanced to organ confined stages in our study. The joinpoint analysis showed significant incidence changes in 1996-1997 and 2001-2002 by disease stage. This may reflect the major changes in diagnostic paradigms and new diagnostic technology in the country.

The rising incidence may be related to the diagnostic improvements and the increasing prevalence of known renal cell cancer risk factors: smoking, obesity, hypertension, and consumption of acetaminophen and non-aspirin nonsteroidal anti-inflammatory drugs (17). The increasing incidence of late-stage renal cell carcinoma and mortality have been described as a confirmation that risk factors are contributing to this upward trend $(18,19)$. In many counties kidney cancer incidence increases consistently with age up until 70-75 years of age and decreases in older age. The drop in incidence rates after 75 years of age is attributed to less frequent diagnostic testing in this group (9). In Lithuania age-specific kidney cancer incidence rates also decrease after the age of 75 years, however, the maximum increase was observed in this particular group. This may indicate that not only diagnostic activities but also changes in risk factor distribution contribute to the increasing incidence of kidney cancer in our country. One possible explanation is related to tobacco smoking prevalence in Lithuania. Tobacco smoke is a multiple-organ-site carcinogen (20). Both current and former smokers have an increased risk of kidney cancer, proportional to smoking intensity (21). In $2014,40.3 \%$ of Lithuanian adult men and $12.3 \%$ of women smoked daily, constituting the biggest gap between sexes in Europe (22). Prospective studies found that overweight and obesity are also associated with an elevated risk of kidney cancer (23). The risk of renal cell carcinoma increases by $24 \%$ for men and $34 \%$ for women with every $5 \mathrm{~kg} / \mathrm{m}^{2}$ increase of the body mass index (24). High prevalence of overweight and obesity is reported in Lithuania in all socio-demographic groups. The prevalence of obesity in Lithuania has increased since 1994 in men and remains high in women (25). Increasing incidence of kidney cancer may also be associated with the growing prevalence of hypertension, although this correlation has been strongly reduced after adjustment for the use of diuretics and other antihypertensive drugs (26). The attributable risk of reported hypertension or treatment with antihypertensive drugs has been estimated to be $21 \%$ overall and 39\% among women (27). Changes in the prevalence of these risk factors in the population could be partly responsible for the increasing kidney cancer incidence in Lithuania.

Stabilization of kidney cancer mortality rates has been reported in Europe (28). Mortality trends in Lithuania are consistent with incidental diagnoses and a downward shift in tumour stage and size (9). A greater understanding of the molecular biology of the disease, surgical advances, and systemic chemotherapy have all likely played a role in decreasing mortality from kidney cancer (29).

The level of kidney mortality is highly dependent on the organisation of urologic oncology and treatment availabilities in a country. In Lithuania, the management of kidney cancer has undergone a transformation in the recent decade. The gold standard for organ-confined kidney cancer remains surgery. Two major surgical techniques applied are radical nephrectomy and nephron- sparing surgery (NSS). Radical nephrectomy more often leads to an impairment of the renal function and cardiovascular events, whereas NSS is non-inferior in terms of overall survival and helps to preserve the renal function, prevents chronic kidney disease, and reduces long-term cardiac morbidity 
(30). As the NSS trend in Lithuania increases (31), it could be associated with mortality trends over past decades.

The gold standard for metastatic kidney cancer is surgical excision and immunotherapy consisting mostly of interferon or interleukin regimens. In other countries, the introduction of tyrosine kinases and mammalian target of rapamycin (mTOR) inhibitor therapies have improved the outcomes, especially for stage IV group (32). Theres are no current data on the impact of targeted therapy on kidney cancer mortality in Lithuania, but in large-scale studies these agents showed improvement of progression-free and overall survival worldwide (33).

Rising incidence of kidney cancer was evident in the Lithuanian population with a stable mortality trend. Most probably, increased kidney cancer incidence rates in Lithuania may be attributed to improved and earlier diagnosis. Consequently, earlier diagnosis and improved survival are reflected in decreasing mortality rates. Increasing kidney cancer incidence in the oldest age group (75 years and above) implies that changes in the prevalence of risk factors in the population may influence incidence changes in Lithuania.

\section{CONCLUSIONS}

The kidney cancer incidence rate in Lithuania was on the rise during 1993-2012 period. The detailed analysis by stage showed the most significant increase in organ confined incidence of kidney cancer. Stable mortality trend for males and decreasing mortality trend for females along with increased incidence of early stage kidney cancer indicate that both earlier detection and modern treatment modalities may contribute to the reduction of mortality.

Received 4 September 2018 Accepted 22 November 2018

\section{References}

1. Cancer Incidence and Mortality Worldwide: IARC CancerBase No. 11 [Internet]. International Agency for Research on Cancer. 2012 [cited 6/7/2016]. Available from: http://globocan.iarc.fr.
2. Znaor A, Lortet-Tieulent J, Laversanne M, Jemal A, Bray F. International variations and trends in renal cell carcinoma incidence and mortality. Eur Urol. 2015; 67(3): 519-30.

3. Murai M, Oya M. Renal cell carcinoma: etiology, incidence and epidemiology. Curr Opin Urol. 2004; 14(4): 229-33.

4. Ljungberg B, Campbell SC, Choi HY, Jacqmin D, Lee JE, Weikert S, et al. The epidemiology of renal cell carcinoma. Eur Urol. 2011; 60(4): 615-21.

5. Li P, Znaor A, Holcatova I, Fabianova E, Mates D, Wozniak MB, et al. Regional geographic variations in kidney cancer incidence rates in European countries. Eur Urol. 2015; 67(6): 1134-41.

6. Vincerževskiene I, Krilaviciute A, Smailyte G. Trends in cancer incidence in Lithuania between 1991 and 2010. Acta Medica Lituanica. 2013; 20(4): 135-46.

7. Dy GW, Gore JL, Forouzanfar MH, Naghavi M, Fitzmaurice C. Global Burden of Urologic Cancers, 1990-2013. Eur Urol. 2017; 71(3): 437-46.

8. Chow WH, Devesa SS. Contemporary epidemiology of renal cell cancer. Cancer J. 2008; 14(5): 288-301.

9. Chow WH, Dong LM, Devesa SS. Epidemiology and risk factors for kidney cancer. Nat Rev Urol. 2010; 7(5): 245-57.

10. Eggener S. TNM staging for renal cell carcinoma: time for a new method. Eur Urol. 2010; 58(4): 517-9; discussion 9-21.

11. Flocks RH, Kadesky MC. Malignant neoplasms of the kidney; an analysis of 353 patients followed five years or more. J Urol. 1958; 79(2): 196-201.

12. Harmen E. TNM classification of malignant tumours. Geneva: Union Internationale Contre le Cancer; 1978.

13. Hermanek P, Sobin L. TNM classification of malignant tumours. 4 ed. Berlin: Springer; 1987.

14. Ficarra V, Schips L, Guille F, Li G, De La Taille A, Prayer Galetti T, et al. Multiinstitutional European validation of the 2002 TNM staging system in conventional and papillary localized renal cell carcinoma. Cancer. 2005; 104(5): 968-74.

15. Pagonas N, Vlatsas S, Westhoff T. Advancements and Breakthroughs in Ultrasound Imaging 2013. London: IntechOpen, 1509-98.

16. Tosaka A, Ohya K, Yamada K, Ohashi H, Kitahara $\mathrm{S}$, Sekine $\mathrm{H}$, et al. Incidence and properties of renal masses and asymptomatic renal cell 
carcinoma detected by abdominal ultrasonography. J Urol. 1990; 144(5): 1097-9.

17. Ebele J, Sauter G, Epstein J, Sesterhenn I. Pathology and genetics of tumours of the urinary system and male genital organs. Lyon: International Agency for Research on Cancer; 2004, 353-10.

18. McCredie M. Bladder and kidney cancers. Cancer Surv. 1994; 19-20: 343-68.

19. Tate R, Iddenden R, Harnden P, Morris E, Craigs C, Bennett $\mathrm{C}$, et al. Increased incidence of renal parenchymal carcinoma in the Northern and Yorkshire region of England, 1978-1997. Eur J Cancer. 2003; 39(7): 961-7.

20. Tobacco Smoke and Involuntary Smoking. Humans IWGotEoCRt, editor. Lyon, France: International Agency for Research on Cancer; 2004.

21. Hunt JD, van der Hel OL, McMillan GP, Boffetta P, Brennan P. Renal cell carcinoma in relation to cigarette smoking: meta-analysis of 24 studies. International journal of cancer. 2005; 114(1): 101-8.

22. Tobacco consumption [Internet]. 2016; 20161207. Available from: http://ec.europa.eu/eurostat/documents/2995521/7762296/3-07122016-AP-EN. pdf/

23. Pischon T, Lahmann PH, Boeing $\mathrm{H}$, Tjonneland A, Halkjaer J, Overvad K, et al. Body size and risk of renal cell carcinoma in the European Prospective Investigation into Cancer and Nutrition (EPIC). Int J Cancer. 2006; 118(3): 728-38.

24. Renehan AG, Tyson M, Egger M, Heller RF, Zwahlen M. Body-mass index and incidence of cancer: a systematic review and meta-analysis of prospective observational studies. Lancet. 2008; 371(9612): 569-78.

25. Kriaucioniene V, Petkeviciene J, Klumbiene J, Sakyte E, Raskiliene A. Socio-demographic inequalities in overweight and obesity among Lithua- nian adults: time trends from 1994 to 2014. Scand J Public Health. 2016; 44(4): 377-84.

26. McCredie M, Stewart JH. Risk factors for kidney cancer in New South Wales, Australia. II. Urologic disease, hypertension, obesity, and hormonal factors. Cancer Causes Control. 1992; 3(4): 323-31.

27. Benichou J, Chow WH, McLaughlin JK, Mandel JS, Fraumeni JF, Jr. Population attributable risk of renal cell cancer in Minnesota. Amer J Epidemiol. 1998; 148(5): 424-30.

28. Levi F, Ferlay J, Galeone C, Lucchini F, Negri E, Boyle $\mathrm{P}$, et al. The changing pattern of kidney cancer incidence and mortality in Europe. BJU international. 2008; 101(8): 949-58.

29. Bhat $S$. Role of surgery in advanced/metastatic renal cell carcinoma. Indian journal of urology: IJU: journal of the Urological Society of India. 2010; 26(2): 167-76.

30. Volpe A, Cadeddu JA, Cestari A, Gill IS, Jewett MA, Joniau $S$, et al. Contemporary management of small renal masses. Eur Urol. 2011; 60(3): 501-15.

31. Milonas D, Skulcius G, Baltrimavicius R, Auskalnis S, Kincius M, Matjosaitis A, et al. Comparison of long-term results after nephron-sparing surgery and radical nephrectomy in treating 4- to 7-cm renal cell carcinoma. Medicina. 2013; 49(5): 223-8.

32. Chiong E, Tay MH, Tan MH, Kumar S, Sim HG, Teh BT, et al. Management of kidney cancer in Asia: resource-stratified guidelines from the Asian Oncology Summit 2012. The Lancet Oncology. 2012; 13(11): e482-91.

33. Ljungberg B, Cowan NC, Hanbury DC, Hora M, Kuczyk MA, Merseburger AS, et al. EAU guidelines on renal cell carcinoma: the 2010 update. Eur Urol. 2010; 58(3): 398-406. 
Aušvydas Patašius, Agnė Ulytė, Albertas Ulys, Giedrè Smailytė

\section{SERGAMUMO INKSTŲ VĖŽIU IR MIRTINGUMO NUO JO POKYČIAI LIETUVOJE 1993-2012 METAIS}

\section{Santrauka}

Ivadas. Tyrimo tikslas - ìvertinti sergamumo inkstų vèžiu ir mirtingumo nuo jo pokyčius 1993-2012 m., naudojant joinpoint regresijos modeli ir vertinant ligos stadijų pasiskirstymo pokyčius.

Medžiaga ir metodai. Tyrimas atliktas remiantis visais inksto vèžio atvejais, registruotais Lietuvos vėžio registre 1993-2012 metais. Standartizuoti sergamumo ir mirtingumo rodikliai buvo skaičiuojami naudojant tiesioginès standartizacijos metodą (standartinè pasaulio populiacija). Joinpoint regresijos modelis buvo naudotas siekiant nustatyti kasmetinị rodiklių pokyti procentais ir aptikti rodiklių lūžio taškus laiko atžvilgiu, kai atsiranda reikšmingi pokyčiai.

Rezultatai. Tyrimo laikotarpiu vyrų sergamumas inkstų vėžiu išaugo nuo 16,89/100 $0001993 \mathrm{~m}$ iki
27,77/100 0002012 m., o moteru - nuo 7,95/100 000 iki $13,44 / 100$ 000. Sergamumas didejo po $2,33 \%$ kasmet tarp vyrų ir po $1,81 \%$ tarp moterų. Joinpoint analizè pagal ligos stadiją parodè didžiausią I-os stadijos inkstų vežio sergamumo augimą, statistiškai reikšmingi sergamumo pokyčiai įvyko $2002 \mathrm{~m}$. tarp vyrų ir 2001 m. tarp moterų. Nuo 1993 iki 2012 m. vyrų ir moterų mirtingumas nuo inkstų vèžio sumažèjo atitinkamai nuo 10,42/100 000 iki 8,96/100 000 ir nuo 4,54/100 000 iki 3,9/100 000 .

Išvados. Sergamumas inkstų vèžiu Lietuvoje 19932012 m. nuosekliai didejo. Sergamumo pokyčių analizè pagal stadijas parodè reikšmingą sergamumo augimą lokalaus inkstų vèžio grupeje. Stabilus mirtingumas nuo inkstų vežzio tarp vyrų ir mažèjantis mirtingumas tarp moterų kartu su augančiu sergamumu ankstyvu stadiju inksto vėžiu rodo, kad stebimas mirtingumo mažèjimas gali būti susijęs su ankstyva diagnostika ir naujomis gydymo galimybèmis.

Raktažodžiai: inkstų vėžys, sergamumas, mirtingumas 